SINAI Journal of Applied Sciences 10 (2) 2021 137-148

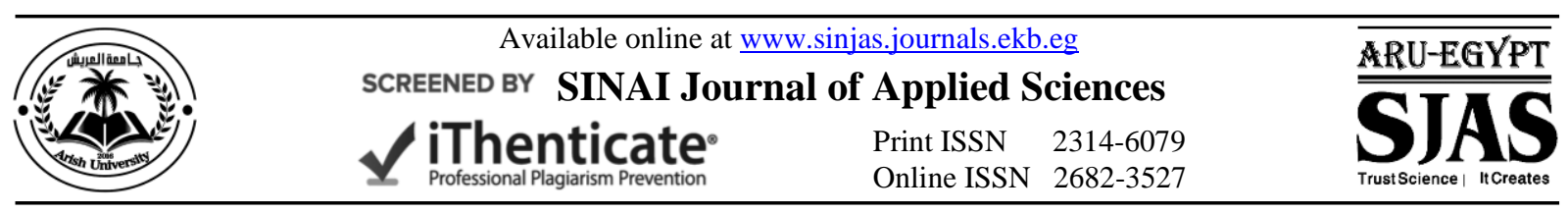

\title{
LENGTH-WEIGHT RELATIONSHIP AND CONDITION FACTOR OF THE BARTAIL FLATHEAD (Platycephalus indicus) IN BARDAWIL LAGOON, NORTH SINAI, EGYPT
}

\author{
Samah A. Kassem ${ }^{*}$, Gaber D. Hassanen ${ }^{1}$, Salem M. Ahmed ${ }^{2}$, Mamdouh A.A. Mousa ${ }^{3}$ \\ 1. Dept. Fisheries and Aquatic Biology, Fac. Environ. Agric. Sci., Arish Univ., Egypt. \\ 2. Fac. Aquacul. and Marine Fisheries, Arish Univ., Egypt \\ 3. Cent. Lab. Aquacul. Res. (CLAR), Egypt.
}

\begin{tabular}{l} 
ARTICLE INFO \\
\hline Article history: \\
Received: $24 / 07 / 2021$ \\
Revised: $24 / 08 / 2021$ \\
Accepted: $19 / 09 / 2021$ \\
Available online: $19 / 09 / 2021$ \\
\hline Keywords: \\
Length weight relationship, \\
condition factor, \\
Bartail Flathead \\
(Platycephalus indicus) \\
and Bardawil lagoon
\end{tabular}

\begin{tabular}{|c|}
\hline \\
Check for \\
updates
\end{tabular}

\begin{abstract}
The present work was carried out to study the length-weight relationships and condition factor of the commercial Bartail Flathead (Platycephalus indicus), in Bardawil lagoon, North Sinai, Egypt. Monthly, random samples of Bartail Flathead (Platycephalus indicus) were collected from the mixed catch of the main landing site at the Bardawil lagoon. 947 specimens of Platycephalus indicus varied from 17.9 to $52.1 \mathrm{~cm}$ with weights ranging between 27.6 and 1003.7 g. were collected from August to December during two fishing seasons 2019-2020. The length-weight relationship of Platycephalus indicus representing were Male: $\mathrm{W}=0.0019 \mathrm{~L}^{3.3502}\left(\mathrm{R}^{2}=0.9677\right)$; Female: $\mathrm{W}=$ $0.0018 \mathrm{~L}^{3.3635}\left(\mathrm{R}^{2}=0.9822\right)$ and Combined sexes: $\mathrm{W}=0.002 \mathrm{~L}^{3.3402}\left(\mathrm{R}^{2}=\right.$ $0.9815)$. The relationship equation showed a positive allometric $(b>3)$; the value of (b) equals $3.3502,3.3635 \mathrm{~cm}$ and $3.3402 \mathrm{~cm}$ for males, females and combined sexes respectively. The condition factor for Platycephalus indicus during the study period was about 0.65 in males, 0.76 in females and 0.76 in combined sexes.
\end{abstract}

\section{INTRODUCTION}

Bardawil lagoon is one of the most important lagoons in Egypt as a source of good quality fish and a habitat for wildlife (Touliabah et al., 2002). The lagoon is considered the main ecological and economic natural resource of North Sinai region (GAFRD, 2001). It has been designated as an Important Bird Area (IBA) by Bird Life International (Noor EI Deen $\boldsymbol{e t}$ al., 2016).

Bartail Flathead (Platycephalus indicus) belongs to Family: Platycephalidae. It includes about 17 genera (Imamura, 1996; Imamura, 2007). The Bartail Flathead, this economic fish has been listed in the Mediterranean Sea coasts as a migratory species through Suez Canal (Rodríguez and Suárez, 2001). It is found at Alataka Harbor, Suez Governorate, Egypt and it is an invasive fish inhabiting the Egyptian coasts and becomes a preferable food for millions of costal peoples (Arafa and Mahmoud, 2019).

Length-weight relationship (LWR) and condition factor are important to study the biology of a fish. It is one of the important morphometric characters that can be used for taxonomy and ultimately in fish stock assessment. This relationship might change over seasons or even days (De Giosa et al., 2014). It is argued that $b$ may change during different time periods illustrating the fullness of stomach, general condition of appetite and gonads stages (Zaher et al.,

\footnotetext{
* Corresponding author: E-mail address: samahkassem23992@gmail.com https://doi.org/10.21608/sinjas.2021.86109.1033

(C) 2021 SINAI Journal of Applied Sciences. Published by Fac. Environ. Agric. Sci., Arish Univ. All rights reserved.
} 
2015). Length-weight relationships also are important for comparative growth studies (Moutopoulos and Stergiou, 2002; Froese, 1998).

Using condition factor $(\mathrm{CF})$ in monitoring growth is also an important way to examine ecological and physiological processes, including death in winter (Ibarz et al., 2010; Dirican et al., 2012). In addition, the $\mathrm{CF}$ is an index of good nutrition (Sutton $\boldsymbol{e t}$ al., 2000).

This work aims to identify biological data for Platycephalus indicus to assess the status of species in Bardawil lagoon to provide the information required and provide fisheries managers with current and reliable biological information about the catch of Platycephalus indicus, which may be useful for improving fisheries in Bardawil lagoon.

\section{MATERIALS AND METHODS}

\section{Study Area}

Bardawil lagoon (Fig. 1) is a large, very saline lagoon nearby the protected area of Zaranik in Egypt on the north coast of the Sinai Peninsula. It is about 30 kilometer (19 mi) long, and 14 kilometer $(8.7 \mathrm{mi})$ wide. It is shallow, reaching a depth of about 3 meters, and is separated from the Mediterranean Sea by a narrow sandbar and often the waters of the sea find their way there, making it saline. (Zahran and Willis, 2008), it is an important source for economical fish and salt production (Abd Elrazek et al., 2006) The fishing is seasonal, starts from the beginning of May to the end of December (El-Ganainy et al., 2002).

\section{Sampling}

Over five months from August to December during two fishing seasons 2019/ 2020, random samples of Bartail Flathead (Platycephalus indicus) were collected from the mixed catch of main the landing site (El-Nasr(A1), Eghzeuan (A2) and ElTulul(A3)) at Bardawil lagoon. 947 specimens of Platycephalus indicus were collected. The total length of $P$. indicus from the tip of the snout to the end of the caudal fin was measured to nearest centimeter, total weight to the nearest 0.1 gram.

\section{Data analysis}

Length-weight relationship was determined by Le Cren (1951) using the following equation:

$$
\mathrm{W}=\mathrm{a} \mathrm{L}^{\mathrm{b}}
$$

$\mathrm{W}=$ is the total weight in gram, $\mathrm{L}=$ is the total length in centimeter and $\mathrm{a} \& \mathrm{~b}$ are constants whose values were estimated by the least square method.

The composite coefficient of condition was calculated monthly during the study period. The coefficient of condition factor was calculated by two methods, namely (Hile, 1936):

$$
\mathrm{Kc}=(\mathrm{W} \times 100) / \mathrm{L}^{3}
$$

$\mathrm{Kc}=$ composite coefficient of condition, $\mathrm{W}$ $=$ weight in $\mathrm{g}$., $\mathrm{L}=$ length in $\mathrm{cm}$.

$$
\mathrm{Kn}=\mathrm{W} / \mathrm{W}^{*}
$$

$\mathrm{Kn}=$ relative coefficient of condition; $\mathrm{W}=$ observed weight in g.; $\mathrm{W}^{*}=$ calculated weight in $\mathrm{g}$.

Statistical analysis for the length-weight relationship and condition factor $(\mathrm{k})$ of the specimens were tested among stations by Microsoft Excel.

\section{RESULTS AND DISCUSSION}

\section{Length-Weight Relationship}

In the present study the total length of combined sexes of the investigated specimens of Bartail Flathead, Platycephalus indicus varied from 17.9 to $52.1 \mathrm{~cm}$ with weights ranging between 27.6 and $1003.7 \mathrm{~g}$. It was used to estimate the length-weight 


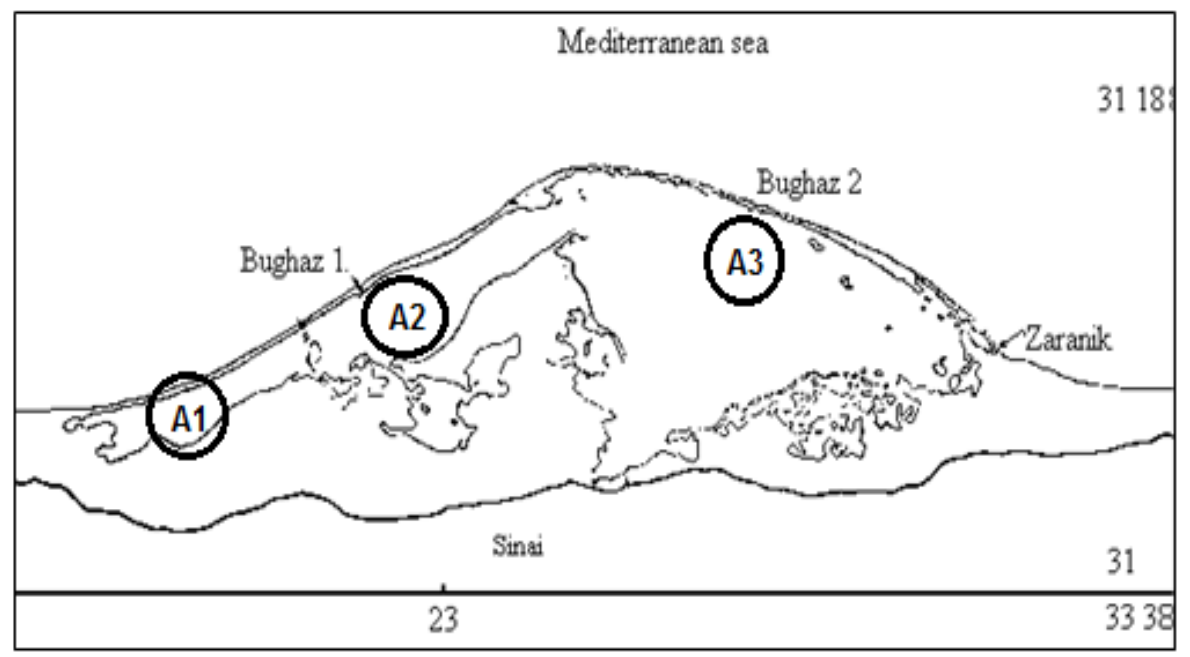

Fig. 1. The map of Bardawil lagoon

relationship of $P$. indicus representing male, female and combined (both sexes) are presented in Figs. 2, 3 and Fig. 4, respectively. The equations thus derived in respect of length-weight relationship are as follows:

Male: $\mathrm{W}=0.0019 \mathrm{~L}^{3.3502}\left(\mathrm{R}^{2}=0.9677\right)$.

Female: $\mathrm{W}=0.0018 \mathrm{~L}^{3.3635}\left(\mathrm{R}^{2}=0.9822\right)$.

Combined sexes: $\mathrm{W}=0.002 \mathrm{~L}^{3.3402}\left(\mathrm{R}^{2}=\right.$ 0.9815).

Length- weight Relationship is used to determine growth in fish (Ighwela et al., 2011). The length-weight relationships can be used for forecasting both the potential yield and determining the most favorable size of capture to obtain optimum yield; these management parameters are directly related to the weight of the fish (Suresh $\boldsymbol{e t}$ al., 2006; Shakman et al., 2008). Length and weight relationship in conjunction with age data can give information on the stock composite, age at maturity, life span, mortality, growth and production. The relative robustness or degree of well-being of a fish expressed as the coefficient of condition (condition factor) is an important tool for the study of fish biology, mainly when the species lies at the base of the higher food web (Diaz et al., 2000; Lizama et al., 2002).
Observed and calculated weight (g.) as well as fish frequency of Platycephalus indicus for male, female and combined sex according to mean of fish length $(\mathrm{cm})$ are shown in Table 1.

The relationship equation showed a positive allometric ( $b>3$ ); the value of (b) equals $3.3502,3.3635 \mathrm{~cm}$ and $3.3402 \mathrm{~cm}$ for males, females and combined sexes respectively. These results agree with (Hashemi et al., 2012) who found that, the value of (b) equals 3.1 for $P$. indicus in Northwest of Persian Gulf, Iran. Mohammadikia et al., (2013) recorded the value of (b) equals 3.1 in coastal waters of Bandar Abbas, Iran, Adeleh et al., (2015) found the value of (b) equals 3.26 in Bahrekan, Persian Gulf, Samir and El Sayed, (2016) found that, the value of (b) equals 3.34 in Port Said, Egypt, Akita and Tachihara, (2019) the value of (b) equals 3.29 in the waters around Okinawa jima Island and also Hajializadeh et al., (2019) find out that, the value of (b) equals 3.16 in northern coastline of Gulf, Oman.

On other hand, the (b) value in this study was higher than that recorded by Naik et al. (1990) where they found that, the values of (b) for the same species equals 2.99 for male, 2.91 for female in Indian waters. And also, higher that recorded by King (2007) in Queensland, Australia where the values of (b) was 3. 
Table 1. Observed and calculated weight for fish frequency of male, female and combined sex according to mean lengths of $P$. indicus collected from Bardawil lagoon during fishing seasons, 2019-2020

\begin{tabular}{|c|c|c|c|c|c|c|c|c|c|c|c|c|}
\hline \multirow{2}{*}{$\begin{array}{c}\text { Length } \\
\text { group } \\
(\mathrm{cm})\end{array}$} & \multicolumn{4}{|c|}{ Male } & \multicolumn{4}{|c|}{ Female } & \multicolumn{4}{|c|}{ Combined sex } \\
\hline & Freq. & $\begin{array}{l}\text { Mean } \\
\text { length }\end{array}$ & $\begin{array}{c}\text { Obs. } \\
\text { Wt. }\end{array}$ & $\begin{array}{l}\text { Cal. } \\
\text { Wt. }\end{array}$ & Freq. & $\begin{array}{l}\text { Mean } \\
\text { length }\end{array}$ & $\begin{array}{l}\text { Obs. } \\
\text { Wt. }\end{array}$ & $\begin{array}{l}\text { Cal. } \\
\text { Wt. }\end{array}$ & Freq. & $\begin{array}{l}\text { Mean } \\
\text { length }\end{array}$ & $\begin{array}{l}\text { Obs. } \\
\text { Wt. }\end{array}$ & $\begin{array}{l}\text { Cal. } \\
\text { Wt. }\end{array}$ \\
\hline 17-17.9 & 0 & 0 & 0 & 0 & 1 & 17.9 & 27.6 & 29.5 & 1 & 17.9 & 27.6 & 30.6 \\
\hline 18-18.9 & 6 & 18.6 & 32.4 & 33.7 & 1 & 18.5 & 31.6 & 32.9 & 7 & 18.5 & 32.3 & 34.4 \\
\hline 19-19.9 & 5 & 19.3 & 38.7 & 38.8 & 4 & 19.4 & 38.8 & 38.6 & 9 & 19.4 & 38.8 & 39.8 \\
\hline $20-20.9$ & 9 & 20.4 & 45.5 & 46.7 & 11 & 20.4 & 43.1 & 45.5 & 20 & 20.4 & 44.2 & 47.4 \\
\hline 21-21.9 & 9 & 21.3 & 51.7 & 53.5 & 17 & 21.5 & 53.5 & 54.6 & 26 & 21.4 & 52.9 & 55.8 \\
\hline 22-22.9 & 15 & 22.4 & 62.8 & 63.6 & 15 & 22.4 & 60.2 & 62.8 & 30 & 22.4 & 61.5 & 64.9 \\
\hline 23-23.9 & 8 & 23.5 & 80.1 & 74.9 & 16 & 23.4 & 73.8 & 72.7 & 25 & 23.4 & 75.4 & 75.3 \\
\hline 24-24.9 & 17 & 24.4 & 89.0 & 85.0 & 17 & 24.2 & 80.3 & 81.4 & 35 & 24.3 & 84.7 & 85.4 \\
\hline $25-25.9$ & 25 & 25.6 & 107.2 & 98.6 & 15 & 25.5 & 94.2 & 96.4 & 40 & 25.5 & 102.3 & 100.0 \\
\hline 26-26.9 & 40 & 26.5 & 114.8 & 111.0 & 10 & 26.5 & 112.3 & 110.0 & 52 & 26.5 & 113.9 & 112.9 \\
\hline 27-27.9 & 36 & 27.4 & 127.6 & 125.2 & 22 & 27.5 & 128.9 & 124.8 & 60 & 27.4 & 127.5 & 127.6 \\
\hline 28-28.9 & 19 & 28.4 & 142.7 & 140.1 & 27 & 28.4 & 144.2 & 138.7 & 48 & 28.4 & 144.1 & 142.8 \\
\hline 29-29.9 & 15 & 29.4 & 165.3 & 157.3 & 24 & 29.5 & 158.1 & 157.3 & 45 & 29.4 & 159.4 & 161.1 \\
\hline $30-30.9$ & 25 & 30.5 & 181.0 & 177.6 & 33 & 30.4 & 171.7 & 174.9 & 71 & 30.4 & 173.9 & 180.0 \\
\hline 31-31.9 & 15 & 31.3 & 192.7 & 195.6 & 34 & 31.4 & 194.8 & 196.0 & 57 & 31.4 & 193.2 & 200.0 \\
\hline 32-32.9 & 11 & 32.3 & 218.7 & 217.0 & 46 & 32.4 & 223.9 & 217.6 & 63 & 32.4 & 219.9 & 222.0 \\
\hline 33-33.9 & 14 & 33.4 & 235.0 & 241.7 & 30 & 33.5 & 249.4 & 243.5 & 45 & 33.5 & 244.6 & 248.0 \\
\hline 34-34.9 & 14 & 34.4 & 265.1 & 267.4 & 22 & 34.4 & 267.4 & 265.4 & 37 & 34.4 & 266.2 & 271.3 \\
\hline 35-35.9 & 11 & 35.5 & 298.9 & 295.4 & 31 & 35.5 & 295.2 & 294.6 & 42 & 35.5 & 296.1 & 300.9 \\
\hline $36-36.9$ & 3 & 36.6 & 331.1 & 327.6 & 25 & 36.5 & 322.8 & 322.9 & 28 & 36.5 & 323.7 & 330.2 \\
\hline $37-37.9$ & 1 & 37.5 & 384.7 & 356.5 & 27 & 37.5 & 360.5 & 354.8 & 28 & 37.5 & 361.3 & 362.3 \\
\hline 38-38.9 & 2 & 38.3 & 353.6 & 382.6 & 24 & 38.4 & 393.7 & 385.1 & 26 & 38.4 & 390.6 & 392.7 \\
\hline 39-39.9 & 0 & 0 & 0 & 0 & 23 & 39.4 & 429.4 & 419.6 & 23 & 39.4 & 429.4 & 428.0 \\
\hline $40-40.9$ & 0 & 0 & 0 & 0 & 17 & 40.5 & 487.0 & 457.8 & 17 & 40.5 & 487.0 & 466.6 \\
\hline 41-41.9 & 0 & 0 & 0 & 0 & 24 & 41.4 & 506.9 & 493.9 & 24 & 41.4 & 504.0 & 503.1 \\
\hline 42-42.9 & 0 & 0 & 0 & 0 & 20 & 42.4 & 512.8 & 535.3 & 20 & 42.4 & 508.8 & 545.0 \\
\hline 43-43.9 & 0 & 0 & 0 & 0 & 13 & 43.4 & 560.2 & 578.4 & 13 & 43.4 & 560.2 & 588.6 \\
\hline 44-44.9 & 0 & 0 & 0 & 0 & 5 & 44.5 & 634.7 & 629.3 & 5 & 44.5 & 634.7 & 640.1 \\
\hline 45-45.9 & 0 & 0 & 0 & 0 & 11 & 45.4 & 681.0 & 672.8 & 11 & 45.4 & 671.9 & 684.0 \\
\hline 46-46.9 & 0 & 0 & 0 & 0 & 15 & 46.4 & 700.3 & 727.9 & 15 & 46.4 & 686.9 & 739.6 \\
\hline 47-47.9 & 0 & 0 & 0 & 0 & 10 & 47.6 & 767.0 & 788.8 & 10 & 47.6 & 767.0 & 801.0 \\
\hline 48-48.9 & 0 & 0 & 0 & 0 & 5 & 48.5 & 781.2 & 840.7 & 5 & 48.5 & 781.2 & 853.4 \\
\hline 49-49.9 & 0 & 0 & 0 & 0 & 4 & 49.3 & 839.4 & 886.5 & 4 & 49.3 & 839.4 & 899.5 \\
\hline $50-50.9$ & 0 & 0 & 0 & 0 & 3 & 50.4 & 900.4 & 960.2 & 3 & 50.4 & 900.4 & 973.8 \\
\hline 51-51.9 & 0 & 0 & 0 & 0 & 1 & 51.5 & 999.9 & 1030.2 & 1 & 51.5 & 999.9 & 1044.3 \\
\hline $52-52.9$ & 0 & 0 & 0 & 0 & 1 & 52.1 & 1003.9 & 1071.2 & 1 & 52.1 & 1003.9 & 1085.5 \\
\hline SUM & 300 & & & & 604 & & & & 947 & & & \\
\hline
\end{tabular}




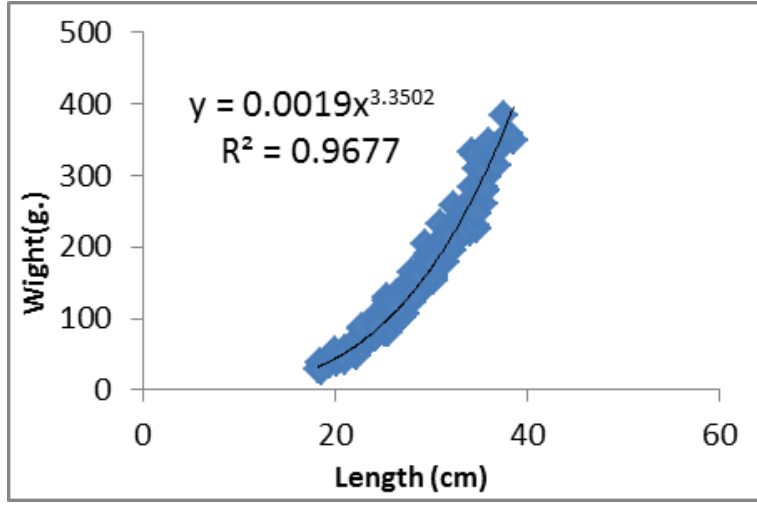

Fig. 2. Length-weight relationship $(ð)$ of $P$. indicus

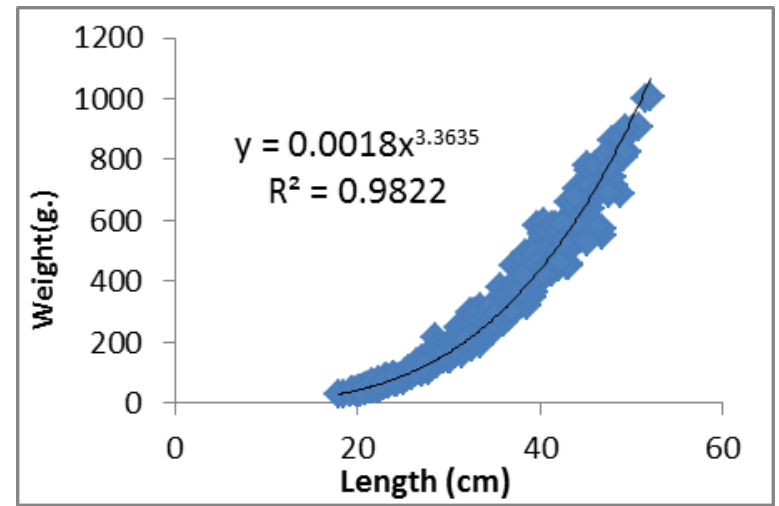

Fig. 3. Length-weight relationship $(+)$ of $P$. indicus

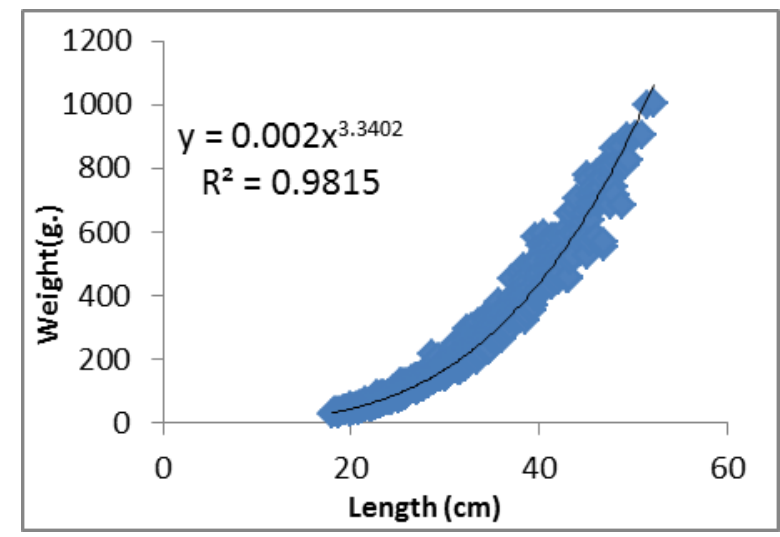

Fig. 4. Length-weight relationship $(q \circlearrowleft)$ of $\boldsymbol{P}$. indicus collected from Bardawil lagoon during two fishing seasons, 2019-2020

The (b) values in fish is species specific and varies with sex, age, seasons, physiological conditions, growth increment and nutritional status of fish, health, habitat, nutrition, environmental conditions (such as temperature and salinity), area, degree of stomach fullness, differences in the length range of the caught specimen, maturity stage and techniques of sampling fishing gear (Tesch, 1968; Le Cren, 1951; Bangenal and Tesch, 1978).

\section{Condition Factor}

Table 2 and Figs. 5, 6 and 7 were used for describing the variation of condition factor with age. Monthly average values of $\mathrm{Kn}$ and $\mathrm{Kc}$ for the period from August to
December 2019-2020 as calculated from the observed total weight and represented of $P$. indicus in Table (3) and figures $(8,9$ and 10) from these tables and figures it is obvious that both composite (Kc) and relative $(\mathrm{Kn})$ condition factor follows the same trends of fluctuations in both males and females.

Kn measures the deviation of an organism from the average weight in a given sample in order to assess suitability of a specific water environment for growth of fish (Yilmaz et al., 2012; Mensah, 2015). An overall fitness for fish species is assumed when Kn values are equal or close to 1 . 
Table 2. Average Kc and $K n(\hat{O}, q$ and $q \hat{\jmath})$ of $P$. indicus collected from Bardawil lagoon during two fishing seasons, 2019-2020

\begin{tabular}{|c|c|c|c|c|c|c|}
\hline \multirow[t]{2}{*}{ Length Group } & \multicolumn{2}{|c|}{ Males } & \multicolumn{2}{|c|}{ Females } & \multicolumn{2}{|c|}{ Combined sexes } \\
\hline & Kc & $\mathbf{K n}$ & Kc & Kn & Kc & $\mathbf{K n}$ \\
\hline 17-17.9 & 0.00 & 0 & 0.48 & 0.94 & 0.48 & 0.90 \\
\hline 18-18.9 & 0.51 & 0.96 & 0.50 & 0.96 & 0.51 & 0.94 \\
\hline 19-19.9 & 0.54 & 1.00 & 0.53 & 1.00 & 0.53 & 0.97 \\
\hline 20-20.9 & 0.53 & 0.97 & 0.51 & 0.95 & 0.52 & 0.93 \\
\hline 21-21.9 & 0.54 & 0.97 & 0.54 & 0.98 & 0.54 & 0.95 \\
\hline 22-22.9 & 0.56 & 0.99 & 0.53 & 0.96 & 0.55 & 0.95 \\
\hline 23-23.9 & 0.61 & 1.07 & 0.57 & 1.01 & 0.59 & 1.00 \\
\hline $24-24.9$ & 0.61 & 1.05 & 0.57 & 0.99 & 0.59 & 0.99 \\
\hline $25-25.9$ & 0.64 & 1.09 & 0.57 & 0.98 & 0.62 & 1.02 \\
\hline 26-26.9 & 0.62 & 1.03 & 0.60 & 1.02 & 0.62 & 1.01 \\
\hline $27-27.9$ & 0.62 & 1.02 & 0.62 & 1.03 & 0.62 & 1.00 \\
\hline 28-28.9 & 0.62 & 1.02 & 0.63 & 1.04 & 0.63 & 1.01 \\
\hline 29-29.9 & 0.65 & 1.05 & 0.62 & 1.01 & 0.63 & 0.99 \\
\hline 30-30.9 & 0.64 & 1.02 & 0.61 & 0.98 & 0.62 & 0.97 \\
\hline 31-31.9 & 0.63 & 0.99 & 0.63 & 0.99 & 0.62 & 0.97 \\
\hline 32-32.9 & 0.65 & 1.01 & 0.66 & 1.03 & 0.65 & 0.99 \\
\hline 33-33.9 & 0.63 & 0.97 & 0.66 & 1.02 & 0.65 & 0.99 \\
\hline 34-34.9 & 0.65 & 0.99 & 0.66 & 1.01 & 0.65 & 0.98 \\
\hline $35-35.9$ & 0.67 & 1.01 & 0.66 & 1.00 & 0.66 & 0.98 \\
\hline $36-36.9$ & 0.68 & 1.01 & 0.67 & 1.00 & 0.67 & 0.98 \\
\hline 37-37.9 & 0.73 & 1.08 & 0.68 & 1.02 & 0.68 & 1.00 \\
\hline 38-38.9 & 0.63 & 0.92 & 0.69 & 1.02 & 0.69 & 0.99 \\
\hline 39-39.9 & 0 & 0 & 0.70 & 1.02 & 0.70 & 1.00 \\
\hline $40-40.9$ & 0 & 0 & 0.74 & 1.06 & 0.74 & 1.04 \\
\hline 41-41.9 & 0 & 0 & 0.72 & 1.03 & 0.71 & 1.00 \\
\hline $42-42.9$ & 0 & 0 & 0.67 & 0.96 & 0.67 & 0.93 \\
\hline 43-43.9 & 0 & 0 & 0.69 & 0.97 & 0.69 & 0.95 \\
\hline 44-44.9 & 0 & 0 & 0.72 & 1.01 & 0.72 & 0.99 \\
\hline $45-45.9$ & 0 & 0 & 0.73 & 1.01 & 0.72 & 0.98 \\
\hline $46-46.9$ & 0 & 0 & 0.70 & 0.96 & 0.69 & 0.93 \\
\hline 47-47.9 & 0 & 0 & 0.71 & 0.97 & 0.71 & 0.96 \\
\hline $48-48.9$ & 0 & 0 & 0.69 & 0.93 & 0.69 & 0.92 \\
\hline 49-49.9 & 0 & 0 & 0.70 & 0.95 & 0.70 & 0.93 \\
\hline $50-50.9$ & 0 & 0 & 0.70 & 0.94 & 0.70 & 0.92 \\
\hline 51-51.9 & 0 & 0 & 0.73 & 0.97 & 0.73 & 0.96 \\
\hline $52-52.9$ & 0 & 0 & 0.71 & 0.94 & 0.71 & 0.92 \\
\hline Average & 0.62 & 1.01 & 0.64 & 0.99 & 0.64 & 0.97 \\
\hline
\end{tabular}


Kassem, et al. | SINAI Journal of Applied Sciences 10 (2) 2021 137-148

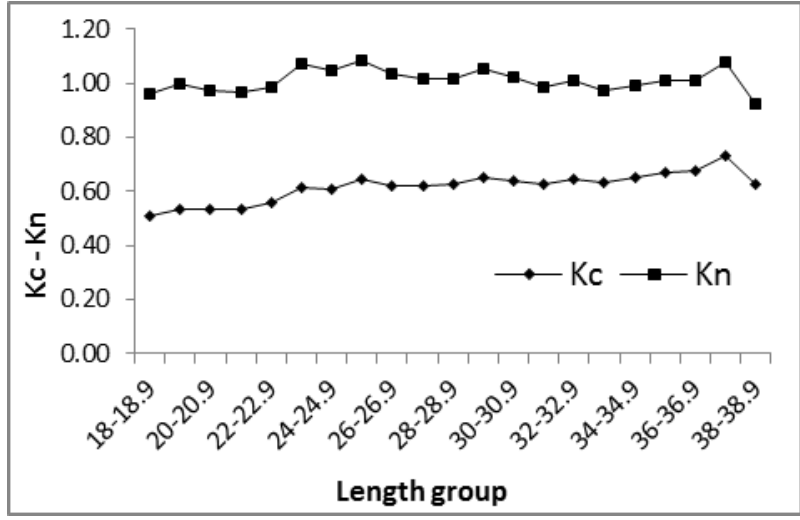

Fig. 5. Average Kc and Kn ( $)$ of $P$. indicus collected from Bardawil lagoon during two fishing seasons, 20192020

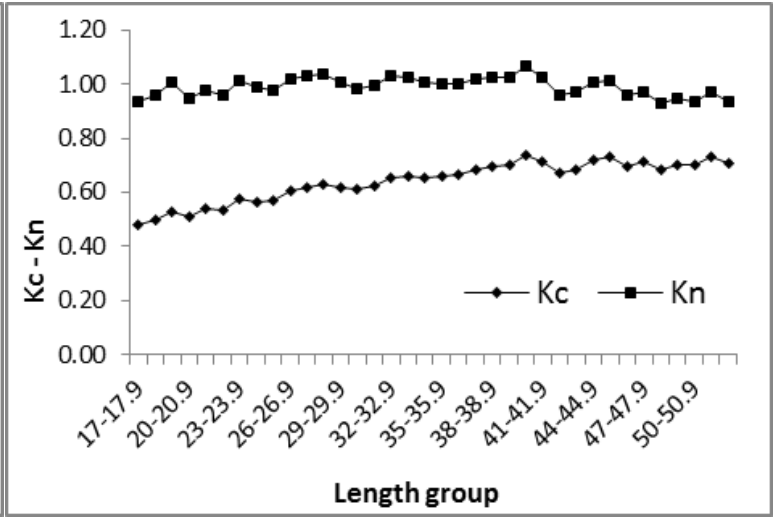

Fig. 6. Average $\mathrm{Kc}$ and $\mathrm{Kn}(\rightarrow)$ of $P$. indicus collected from Bardawil lagoon during two fishing seasons, 20192020

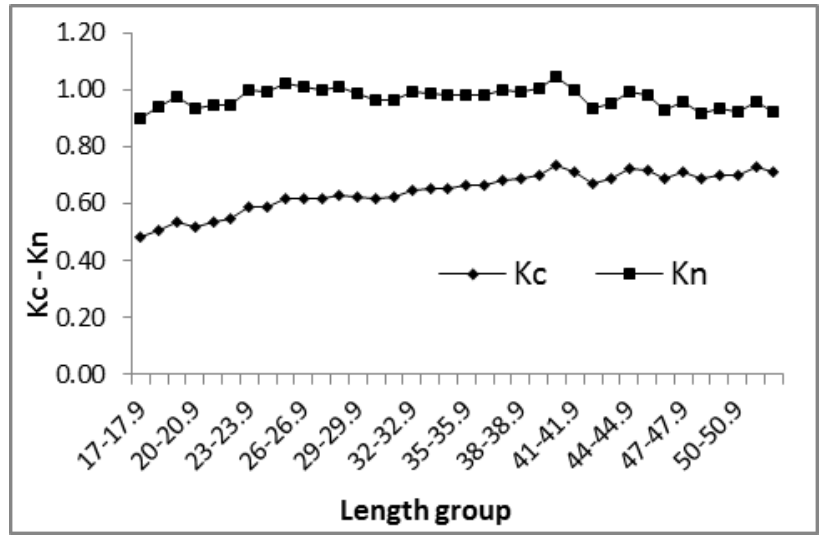

Fig. 7. Average $\mathrm{Kc}$ and $\mathrm{Kn}(\hat{\jmath}+)$ of $\boldsymbol{P}$. indicus collected from Bardawil lagoon during two fishing seasons, 2019-2020

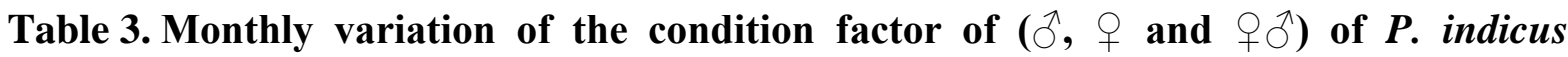
collected from Bardawil lagoon during two fishing seasons, 2019-2020

\begin{tabular}{ccccccc}
\hline Month & \multicolumn{2}{c}{ Males } & \multicolumn{2}{c}{ Females } & \multicolumn{2}{c}{ Combined sexes } \\
\cline { 2 - 7 } & Kc & Kn & Kc & Kn & Kc & Kn \\
\hline Aug. & 0.64 & 1.06 & 0.76 & 1.17 & 0.75 & 1.16 \\
Sep. & 0.58 & 1.01 & 0.73 & 1.15 & 0.72 & 1.13 \\
Oct. & 0.67 & 1.09 & 0.75 & 1.15 & 0.74 & 1.14 \\
Nov. & 0.70 & 1.13 & 0.80 & 1.22 & 0.80 & 1.21 \\
Dec. & 0.63 & 1.06 & 0.79 & 1.20 & 0.79 & 1.20 \\
average & 0.65 & 1.07 & 0.76 & 1.18 & 0.76 & 1.17 \\
\hline
\end{tabular}




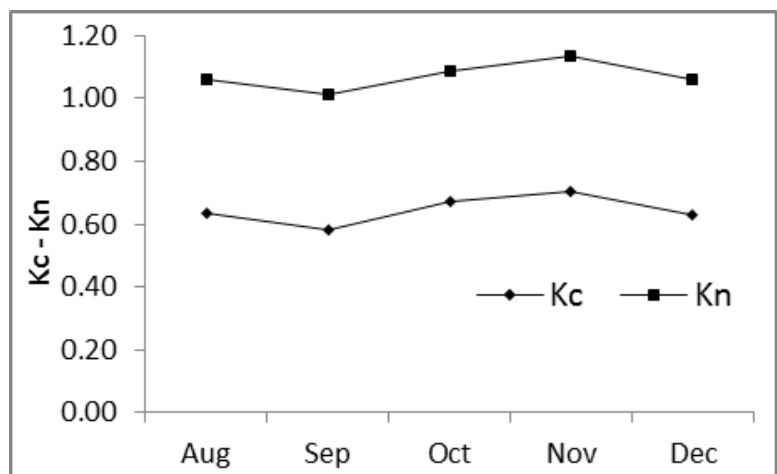

Fig. 8. Monthly variation of the condition factor $(\stackrel{)}{)})$ of $P$. indicus collected from Bardawil lagoon during two fishing seasons, 2019-2020

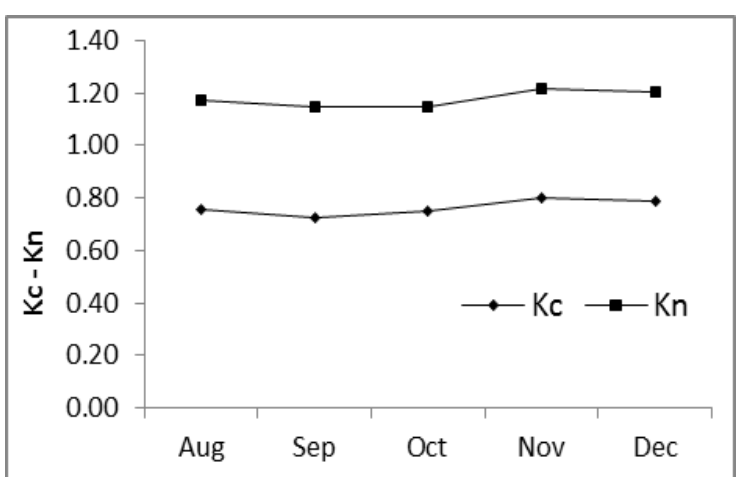

Fig. 9. Monthly variation of the condition factor $(+)$ of $\boldsymbol{P}$. indicus collected from Bardawil lagoon during two fishing seasons, 2019-2020

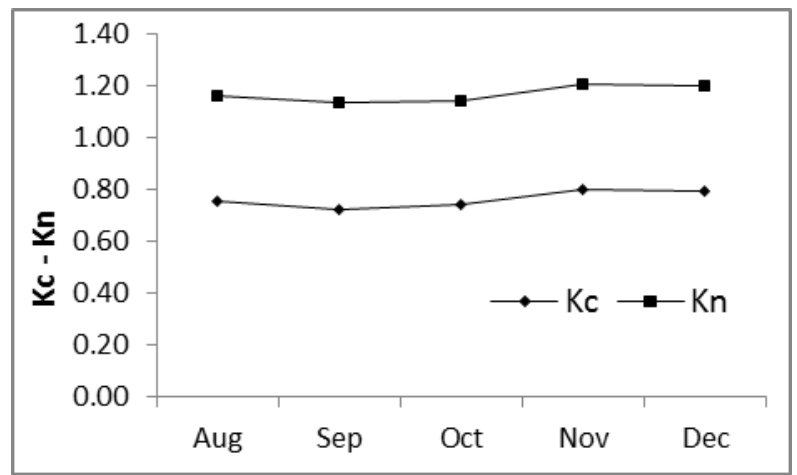

Fig. 10. Monthly variation of the condition factor $(\uparrow \triangleleft)$ of $\boldsymbol{P}$. indicus collected from Bardawil lagoon during two fishing seasons, 2019-2020

In the present study, the condition factor for $P$. indicus during period study was about 0.65 in males, 0.76 in females and 0.76 in combined sexes. The highest $\mathrm{K}$ value was observed in November and December. Results indicated that condition factor $\mathrm{k}$ decrease with increase in length of the fish in both females and males. This result is similar to that obtained by Hashemi et al., (2012) in Northwest of Persian Gulf, Iran (K- factor was 0.71 0.75 for males and females respectively). Also, these results disagree with Al Mudhaffar, (2017) who found that, the condition factor $(\mathrm{Kc})$ was 1.72 for males and 1.92 for females for the same species in Iraqi Marine Waters.
The condition factor, according to the researchers, compares a fish's well-being and is based on the notion that heavier fish of a particular length are in better condition (Bangenal and Tesch, 1978). The condition factor has been utilized as a growth and feeding intensity indicator (Fagade, 1979). The reproductive cycle of fish is influenced by the condition factor (Welcom, 1979).

\section{REFERENCES}

Abd Elrazek, F.; Taha, S. and Ameran, A. (2006). Pulation biology of the edible crab Portunus pelagicus (Linnaeus) from 
Bardawil Lagoon, northern Sinai, Egypt.

Egypt. J. Aquatic Res., 32: 401-418.

Adeleh, H.; Hakimeh, F. and Hamed M. (2015). Length-weight relationship of bartail flathead fish (Platycephalus indicus: Platycephalidae) in Bahrekan fishing area, Persian Gulf.

Akita, Y. and Tachihara, K. (2019). Age, growth, and maturity of the Indian flathead Platycephalus indicus in the waters around Okinawa-jima Island, Japan. Published online, ISSN 13418998. Ichthyol Res 66, 330-339. https://doi.org/10.1007/s10228-019-00680-2

Al Mudhaffar, A.A.R. (2017). Some Aspect of Reproductive biology of Bartail Flathead (Platycephalus indicus, Linnaeus, 1758) in Iraqi Marine Waters Northwest Arabian Gulf. Al-Kufa Univ. J. for Biol., 9(1): 2073-8854.

Arafa, S.Z. and Mahmoud, A.S. (2019). Ultrastructural investigations of vitellogenesis and oogenesis of Proctoeces sp. infesting Platycephalus indicus fishes caught from Alataka Harbor, Suez Gulf, Egypt. Egyptian J. Aquatic Biol. and Fisheries Zool. Dept., Fac. Sci., Ain Shams Univ., Cairo, Egypt. ISSN 1110-613., 23(5): 439-450.

Bangenal, T.B. and Tesch, F.W. (1978). Age and Growth in Methods for Assessment of Fish Production in Fresh waters. IBP Handbook NO.3. T. Bagenal (Ed.). Blackwell Scientific Publications, Oxford: 101-136.

De Giosa, M.; Czerniejewski, P. and Rybczyk, A. (2014). Seasonal changes in condition factor and weight-length relationship of invasive carassius gibelio (Bloch, 1782) from Leszczynskie Lakeland, Poland. Adv. Zool.

Diaz, L.S.; Roa, A.; Garcia, C.B.; Acero, A. and Navas, G. (2000). Length-weight relationship of demersal fishes from the upper continental slope off Columbia. NAGA, 23(3): 23-25.
Dirican, S.; Musul, A. and Cilek, S. (2012). Condition factors of some Cyprinid fishes of Kilickaya Reservoir, Sivas, Turkey. Indian J. Anim. Res., 46 (2): $172-175$.

El-Ganainy, A.A. and Ahmed, A.I. (2002). Growth, mortality and yield -perrecruit of the rabbitfish, Siganus rivulatus, from the eastern sid of the Gulf of Suez, Sinai Coast, Egypt. J. Aquat. Biol. and Fish., 6 (1): 67-81.

Fagade, S.O. (1979). Observations on the biology of two species of Tilapia from the Lagos Lagoon, Nigeria. Bull. Inst. Français d'Afr. Noire, 41 A(3):629-653.

Froese, R. (1998). Length-weight relationships for 18 less studied fish species. J. Appl. Ichthyol., 14:117-118.

GAFRD (2001). Report (General Authority for Fish Resources Development) on Bardawil lagoon.

Hajializadeh, P.; Salahi, M.; Hashemi, S.H.; Kamrani, E. and Salarpouri, A. (2019). Length and weight relationships of three fish species from Jask mangrove protected area in northern coastline of Gulf of Oman (Hormozgan, Iran): Liza klunzingeri (Day, 1888), Cociella crocodilus (Cuvier, 1829) and Platycephalus indicus (Linnaeus, 1758). J Appl Ichthyol; 35: 1042- 1043.

Hashemi, S.A.; Taghavimotlagh, S.A. and Eskandary, G. (2012). Some biological Aspect of Bartail Flathead (Platycephalus indicus Linnaeus, 1758) in Northwest of Persian Gulf (Khuzestan Coastal Waters, Iran). World J. Fish and Marine Sci., 4 (2): 185-190.

Hile, R. (1936). Age and growth of the Cisco Leucichthys arted in the lakes of the north eastern high lands, Wisconsin. Bull. U.S. Bur. Fish., 48: 211-317.

Ibarz, A.; Padròs, F.; Gallardo, M.A.; Fernàndez-Borràs, J.; Blasco, J. and Tort, L. (2010). Low-temperature 
challenge to gilthead seabream culture: review of cold-induced alteration and "Winter Syndrome". Reviews in Fish Biology and Fisheries, 20: 539-556. doi: 10.1007/s11160-010-9159.

Ighwela, K.A.; Ahmed A.B. and AbolMunafi A.B. (2011). Condition factor as an indicator of growth and feeding intensity of Nile Tilapia fingerlings (Oreochromis niloticus) Feed on different levels of Maltose. AmericanEurasian J. Agric. and Environ. Sci., 11 (4): 559-563,

Imamura, H. (1996). Phylogeny of the family Platycephalidae and related taxa (Pisces: Scorpaeniformes). Speces Diversity 1: 123-233.

Imamura, H. (2007). Rogadius mcgroutheri, a new species of flathead (Teleostei: Platycephalidae) collected from eastern Australia and New Caledonia. Ichthyological Res., 54: 307.

King, M. (2007). Fisheries Biology and Assessment and Management. Fishing news press, 340 .

Le Cren, E.D. (1951). The length-weight relationship and seasonal cycle in gonad weight and condition in the Perch (Perca fluviatilis). J. Anim. Ecol., 20: 201-219.

Lizama, M.; De Los, A.P. and Ambrósio (2002). Condition factor in nine species of fish of the Characidae family in the Upper Parana River floodplain, Brazil. Braz. J. Biol., 62(1): 113-124.

Mensah, S.A. (2015). Weight-length models and relative condition factors of nine freshwater fish species from the Yapei Stretch of the White Volta, Ghana Elixir. Appl. Zool., 79: 30427-30431.

Mohammadikia, D.; Kamrani, E.; Taherizadeh, M.R. and Saghar, N. (2013). A comparison study on some biological aspects of Platycephalus indicus in coastal waters of Bandar Abbas. J. Aqu. Eco., 2(3): 56-41.
Moutopoulos, D.K. and Stergiou, K.I. (2002). Length-weight and length-length relationships of fish species from Aegean Sea (Greece). Appl. Ichthyol., 18: 200-203.

Naik, S.K.; Shanbhogue, S.L.; Jayabalan, N. and Krishna-Bhat, C. (1990). Observations on Platycephalus indicus from the NetravatiGurpur Estuary, Mangalore. Environ. Ecol., 8 (4): 13111313.

Noor El Deen, A.I.E.; Eissa, I.A.M.; Mehana, S.F.; El-Sayed, A.B. and Zaki M.S. (2016). Ecology of Lake Bardawil: A Preliminary Review, Int. J. Environ. Sci., 5 (1): ISSN: 2277-1948.

Rodríguez, G. and Suárez, H. (2001). Anthropogenic dispersal of decapod crustaceans in aquatic environments. Intercien., 26 (7): 282-288.

Samir, I.R. and El Sayed, H.Kh. Akel. (2016). A contribution to biometric analysis and length- weight relationship of Platycephalus indicus (Linnaeus, 1758) obtained off Port Said (Egyptian Mediterranean waters). Acta Velit, 3 (1), ISSN: 2394-3092.

Shakman, E.; Winkler, H.; Oeberst, R. and Kinzelbach, R. (2008). Morphometry, age and growth of Siganus luridus Rüppell, 1828 and Siganus rivulatus Forsskål, 1775 (Siganidae) in the central Mediterranean (Libyan coast). Revista de Biología Marina y Oceanografía, 43: 521-529.

Suresh, V.R.; Biswas, B.K.; Vinci, G.K.; Mitra, K. and Mukherjee, A. (2006). Biology and Fishery of Bared Spiny eel, Macrognathus pancalus Hamilton. Actaichthyologica et Piscatoria 36 (1), 31-37.

Sutton, S.G.; Bult, T.P. and Haedrich R.L. (2000). Relationships among fat weight, body weight, water weight, and condition factors in wild Atlantic 
Salmon Parr. Transactions Ame. Yilmaz, S.; Yazıcıoğlu, O.; Erbaşaran, Fisheries Soc., 129: 527-538.

M.; Esen, S.; Zengin, M.; Polat, N. (2012). Length-weight relationship and relative condition factor of white bream, Blicca bjoerkna (L., 1758), from Lake Ladik, Turkey J. Black Sea/Medit. Environ., 18: 380-387 Oxford, 93-123.5.

Touliabah, H.; Safik, H.; Gab-Allah, M. and Taylor, W. (2002). Phytoplankton and some abiotic features of El-Bardawil Lake, Sinai, Egypt. Afr. J. Aquat. Sci. 27: 97-105.

Welcom, R.L. (1979). Fisheries Ecology of Flood plain Rivers. Longman, 317.

Zaher, F.M.; Rahman, B.M.S.; Rahman, A.; Alam, M.A. and Pramanik, M.H. (2015). Length-weight relationship and GSI of hilsa, Tenualosa ilisha (hamilton, 1822) fishes in Meghna river, Bangladesh, Int. J. Nat. Soc. Sci., 2: 82-88.

Zahran, M.A. and Willis, A.J. (2008). The Vegetation of Egypt. Springer Science \& Business Media. ISBN 9781402087561. 


$$
\text { الملخص العربي }
$$

العلاقة بين الطول والوزن ومعامل الحالة لسمكة الرقد، (Platycephalus indicus) بمنخفض

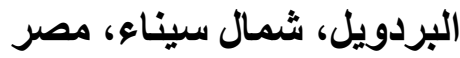

سماح أحمد قاسم، جابر دسوقي حسنين1، محمد سالم أحمد، ممدوح عبدالعزيز علي موسى 3

1. قسم الثروة السمكية والأحياء المائية، كلية العلوم الزر اعية البيئية، جامعة العريش، مصر.

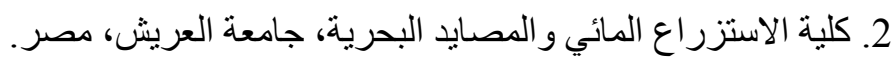

3. المعمل المركزي لبحوث الثروة السمكية (CLAR)، مصر.

تم إجر اء هذا العمل لدر اسة العلاقات بين الطول والوزن ومعامل الحالة لسمكة الرقد (Platycephalus indicus)، في بحيرة البردويل، شمال سيناء، مصر. تم جمع عينات شهرية بشكل عشو ائي لسمك الرقد (Platycephalus indicus)

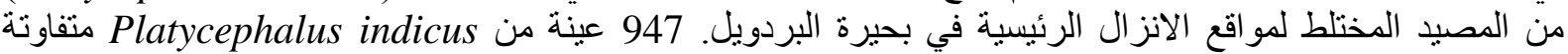

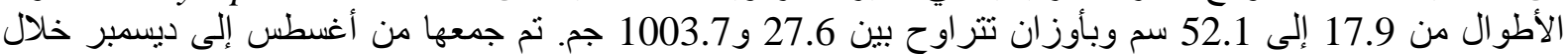
موسمي الصيد 2020-2019. تمنلت العلاقة بين الطول و الوزن لاسماك الرقدانس

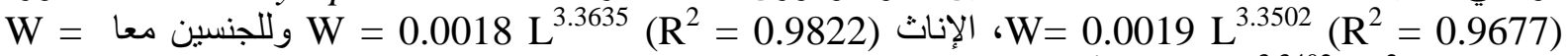

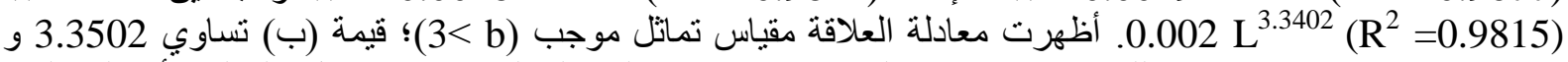

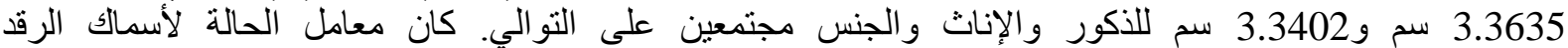
Platycephalus indicus الكلمات الاسترشادية: علاقة الطول بالوزن، معامل الحالة، سمكة الرقد (Platycephalus indicus) ومنخفض البردويل.

أستاذ بيولوجيا الأسمالك، كلية تكنولوجيا المصايد و الأسمالك، جامعة أسوان، مصر.

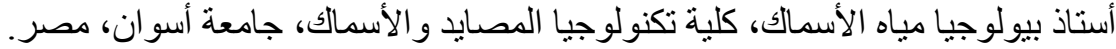

